\title{
Effects of High Power Ultrasonic Pretreatment on Physicochemical Quality and Enzymatic Activities of Dried Longan
}

\author{
Thanyanun Rithmanee ${ }^{1} \&$ Pilairuk Intipunya ${ }^{1}$ \\ ${ }^{1}$ Division of Food Science and Technology, Faculty of Agro-Industry, Chiang Mai University, Thailand \\ Correspondence: Pilairuk Intipunya, Division of Food Science and Technology, Faculty of Agro-Industry, \\ Chiang Mai University 155, Moo 2, Mae Hia sub-district, Mueang Chiang Mai district, Chiang Mai province, \\ Thailand. Tel: 66-895-613-596. E-mail: pilairuk.intipunya@cmu.ac.th
}

Received: July 20, 2012 Accepted: August 13, 2012 Online Published: October 17, 2012

doi:10.5539/jas.v4n11p299 URL: http://dx.doi.org/10.5539/jas.v4n11p299

\begin{abstract}
The physicochemical quality and inactivation of polyphenol oxidase (PPO), peroxidase (POD) in dried longan with high power ultrasonic pretreatment was investigated. Effect of high power ultrasonication was compared with a traditional chemical pretreatment with potassium metabisulfite and non-pretreatment. Chemical qualities, such as $\mathrm{a}_{\mathrm{w}}, \mathrm{MC}$, TSS, and TA of the ultrasonic pretreated dried longan samples were significantly lower than those of the control samples $(P \leq 0.05)$, whereas their $\mathrm{pH}$ were higher than those of the control samples. Increase in ultrasonication time resulted in decreases of $\mathrm{a}_{\mathrm{w}}, \mathrm{MC}$, TSS, and TA, but an increase of $\mathrm{pH}$. The firmness, lightness $\left(\mathrm{L}^{*}\right)$, and yellowness $\left(\mathrm{b}^{*}\right)$ values increased and redness $\left(\mathrm{a}^{*}\right)$ values decreased when the sample was pretreated with increasing ultrasonication time. The application of high power ultrasonic pretreatment for 10, 20, and 30 min could reduce PPO activity by $49.99 \%, 57.18 \%$, and $70.68 \%$, and POD activity by $47.63 \%, 86.16 \%$, and $94.06 \%$, respectively. The PPO and POD activities were significantly decreased with increasing ultrasonication time. Panelists were most satisfied with sensory properties of the dried longan with $30 \mathrm{~min}$ of high power ultrasonic pretreatment.
\end{abstract}

Keywords: longan, high power ultrasound, enzymatic inactivation, drying

\section{Introduction}

Longan (DimocarpuslonganLour.) is a well-known commercial crop in northern Thailand. Its fruits are commonly processed into dried products for export, mainly to China (Achariyaviriyaet al., 2001; Janjaiet al., 2007). The longan fruit is processed in the form of dried longan as a high value-added product. However, a major problem of the dried-longan pulp products is an extreme short shelf life due to the enzymatic and non-enzymatic browning reactions during processing and storage. The enzymatic browning reactions are important problem in the dehydrated fruit and vegetable products because they often produce undesirable colorsand flavors (Shewfelt, 1987). This reaction is due to oxidation of phenolic compounds caused by polyphenol oxidase (PPO) and peroxidase (POD), and further produces brown pigments. Currently, there are different chemical agents used to control the enzymatic browning such as phenolic acids, sulfites, ascorbic acid and cysteine (Pongsakul et al., 2006). However, these chemical agents, especially bisulfites, are dangerous for human health because of acute allergic reaction. Thus, alternative treatments without toxic effects are required.

One of the alternative methods to inactivate enzymes are pre-drying treatment. Pre-drying treatments are commonly applied in order to minimise adverse changes during drying and to achieve faster, more effective drying and extended storage life. High power ultrasonic pretreatment has been a practical interest in many processes. High power ultrasound has been applied in pretreatment for common dehydration (Rodrigues \& Fernandes, 2007; Fernandes et al., 2008a). High power ultrasound can increase the effectiveness of enzymatic inactivation by heat and has been demonstrated in enzymes derived from plants (horseradish peroxidase, watercress peroxidase, mushroom polyphenol oxidase, and orange pectinmethylesterase), animal tissues (porcine heart malate dehydrogenase, rabbit muscle L-lactic dehydrogenase, and trypsin), microorganisms (Pseudomonas fluorescenslipase and protease, alcohol dehydrogenase, and $\beta$-galactosidase from Escherichia coli), and milk (bovine lactoperoxidase, alkaline phosphatase, and lactoperoxidase). The stabilityof individual proteins varies among enzyme types and also depends on ultrasonic treatment conditions, the composition of the treatment medium, treatment $\mathrm{pH}$, and whether they are bound (e.g., membrane-bound proteins) or free (e.g., cytoplasmic 
proteins). Enzymatic inactivation generally increases with increasing ultrasonic power, frequency, amplitude, exposure time, cavitation intensity, processing temperature, and processing pressure, but decreases with increasing treatment volume (Torley \& Bhandari, 2007).

The effectiveness of ultrasound frequency, time and intensity tends to depend on the particular combination of materials, drying conditions and ultrasound systems (Da-Mota \& Palau, 1999). Under exposure to high power ultrasound, structure of plant tissue can be modified. Subsequently, the effective moisture diffusion rate is increased during drying. This is due to microchannel generation during alternative compressions and expansions exerted by the ultrasonic waves (de la Fuente-Blanco et al., 2006). These microchannels facilitate moisture transfer during drying (Fernandes et al., 2010). The combination of ultrasound and air drying has been shown to increase the rate of drying in various products, including carrot (Gallego-Juarez et al., 1999), apple (Simal et al., 1998; Cárcel et al., 2007), melon (Fernandes et al., 2008a), papaya (Fernandes et al., 2008b), banana (Fernandes \& Rodrigues, 2007) and pineapple (Fernandes et al., 2009). Ultrasonic pretreatment was found to increase water diffusivity of fruits during drying (Fernandes \& Rodrigues, 2007). Therefore, this pretreatment can also be an alternative process to produce dried longan.

This research investigated the use of high power ultrasound for pretreatment of longan prior to air-drying. With possible improvements on product quality attributes and drying process efficiency, pretreatment with high power ultrasound exhibits a great potential to be used for longan drying. It is expected that the pretreatment will assist in enzymatic inactivation and improve qualities of the dried longan.

\section{Materials and Methods}

\subsection{Preparation of Samples}

Longan (Dimocarpus longan Lour.) cv. Daw fruits with AA size (diameter about $3 \mathrm{~cm}$ ) was seeded, peeled and washed. The sample contained approximately 15 Brix of total soluble solid. 3,000 ppm potassium metabisulfite (KMS) was used for 5 min pretreatment (Attabhanyo \& Tiampakdee, 1998). Samples were freshly prepared for each treatment.

\subsection{High Power Ultrasonic Pretreatment}

Peeled longans were sonicated for 10, 20, and 30 min using a high intensity ultrasonic processor (VC 130, USA.) with ultrasonic probe system at 130 Wand low frequency $(20 \mathrm{kHz})$. The probe was immersed in distilled water containing the sample and the sample was circulated during the treatment by a magnetic stirrer. Final temperature of the liquid medium reached $29^{\circ} \mathrm{C}, 31^{\circ} \mathrm{C}$, and $32.5^{\circ} \mathrm{C}$ after 10,20 , and 30 min ultrasonication, respectively. At the end of the high power ultrasonic pretreatment, the samples were drained and gently blotted with absorbent paper and transferred to hot air drying process. The sample not subjected to the ultrasound treatment was used as a control sample.

\subsection{Hot Air Drying}

The pretreated and control samples were dried in a hot air dryer (Tray dryer, Navaloy, Thailand) at $60^{\circ} \mathrm{C}$ and air velocity of $0.5 \mathrm{~m} / \mathrm{s}$. MC of the samples during drying was measured by weighing the fruit samples at every 10 min for the first $3 \mathrm{hr}$ of drying and then at every $30 \mathrm{~min}$ until reaching constant weight. The 10, 20, and $30 \mathrm{~min}$ ultrasonic pretreated dried samples were marked as "UP10", "UP20", and "UP30", respectively, whereas the sample pretreated with potassium metabisulfite was marked as "KMS" and the control sample as "control".

\subsection{Chemical Analysis}

Physico chemical properties of dried longan were analyzed as follows:

\subsubsection{Determination of PPO Activity}

To extract polyphenoloxidase (PPO), dried longan ( $3 \mathrm{~g}$ ) was homogenized in $20 \mathrm{ml}$ of $0.1 \mathrm{M}$ phosphate buffer ( $\mathrm{pH}$ 6.8) and the homogenate was filtered and then centrifuged at $12,000 \mathrm{~g}$ for $20 \mathrm{~min}$ at $4^{\circ} \mathrm{C}$. The clear supernatant was collected as enzyme extract. PPO activity was assayed following the method of Jiang \& Li (2001) by measuring the oxidation of pyrocatechol. The increasing absorbance at $420 \mathrm{~nm}$ during incubation at $45^{\circ} \mathrm{C}$ was recorded at every $15 \mathrm{~min}$ for $60 \mathrm{~min}$ using a UV-Vis spectrophotometer (Lambda 35, Perkin Elmer, USA). One unit of enzymatic activity is defined as the amount that causes a change of 0.001 in absorbance per minute.

\subsubsection{Determination of POD Activity}

The enzyme extract (as in section 2.4.1) was assayed for POD activity following the method of Lin et al. (1988).

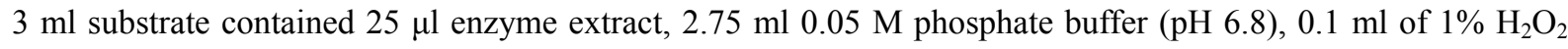


and $0.15 \mathrm{ml}$ of $4 \%$ guaiacol. The increase in absorbance at $470 \mathrm{~nm}$ was recorded at every 2 min for 10 min using a UV-Vis spectrophotometer (Perkin Elmer series Lambda35, USA). One unit of enzymatic activity was defined as the amount that causes a change of 0.001 in absorbance per minute.

\subsubsection{Percentage Inhibition of Enzyme Activities}

Percentage inhibition of PPO and POD activities were calculated as the percentages of reduction based on those of the control sample.

\subsubsection{Water Activity $\left(\mathrm{a}_{\mathrm{w}}\right)$}

Water activity of the samples was analyzed using an AquaLab Water Activity Metre (Decagon, USA).

\subsubsection{Moisture Content (MC)}

Moisture content of samples was analyzed according to AOAC method (AOAC, 2000) by an oven method at $105^{\circ} \mathrm{C}$.

\subsubsection{Total Soluble Solid Content (TSS)}

$10 \mathrm{~g}$ of dried longan were homogenized with $100 \mathrm{ml}$ distilled water. TSS of the samples were determined with a Pocket Refractometer (N-10E, Atago, Japan). Results were expressed in Brix (Kaewnarin, 2008).

\subsubsection{Titratable Acidity (TA)}

Titratable acidity (expressed as \% citric acid) of longan samples was analyzed in accordance with the method of AOAC (AOAC, 2000).

\section{$2.4 .8 \mathrm{pH}$}

The $\mathrm{pH}$ of the samples was measured using a digital $\mathrm{pH}$ meter (pH 510, Eutech Instruments, Singapore) in accordance with the method of AOAC (AOAC, 2000).

\subsection{Physical Analysis}

\subsubsection{Color Measurement}

Color parameters $\left(a^{*}\right.$ (redness value), $b^{*}$ (yellowness value) and $L^{*}$ (lightness value)) of samples were determined using a Minolta colorimeter (CR-300, Minola, Japan).

\subsubsection{Firmness}

Firmness of the samples was evaluated using a Texture Analyzer (TA-XT Plus, UK) with a Warner Bratzler blade set. The blade travelling speed was set at $1 \mathrm{~mm} / \mathrm{s}$, and distance traveled by the blade through the sample was 30 $\mathrm{mm}$ in order to make a complete cut of the samples. The maximum force used to cut the sample was recorded as the firmness value of the dried sample. Maximum shear force was expressed as Newton $(\mathrm{N})$. The test was accomplished with 10 replications.

\subsection{Sensory Evaluation}

Sensorial preference of the samples was evaluated using 9-point Hedonic scale (ranking from 9-like extremely to 1-dislike extremely) by 50 untrained panelists aged between 18-40 years old. Sample preference was evaluated in terms of color, odor, sweetness, stickiness, and overall preferences (Walkling-Ribeiro et al., 2009). Stickiness refers to chewy texture of the sample.

\subsection{Experimental Design and Statistical Analysis}

The experiment was conducted in triplicate using a Complete Randomized Design (CRD). The experimental results were subjected to analysis of variance (ANOVA) and Duncan's multiple range tests. The significant differences between means were defined at $P \leq 0.05$.

\section{Result and Discussion}

From Table 1, $\mathrm{a}_{\mathrm{w}}, \mathrm{MC}$, TSS, TA and $\mathrm{pH}$ of dried longan with different pretreatment methods were significantly different as compared to those of control samples $(P \leq 0.05)$. The $\mathrm{a}_{\mathrm{w}}$, MC, TSS and TA of dried longan pretreated with high power ultrasound were significantly lower than those of control samples. The decrease of TSS varies from 14.27 to 12.10. TSS of KMS and ultrasonic pretreated samples were significantly decreased due to leaching out of some sugar into the ultrasonicating medium (water). The increase in ultrasonication time did not cause significant reduction in TSS $(P>0.05)$. The increase of $\mathrm{pH}$ varies from 6.75 to 7.09 by ultrasonication. The $\mathrm{pH}$ of dried longan with 30 min ultrasonic pretreatment was significantly increased $(P \leq 0.05)$. This may due to a leaching of ionizable components from longan flesh into liquid medium during ultrasonication. 
The final MC and $\mathrm{a}_{\mathrm{w}}$ of dried longan decreased with increasing ultrasonic pretreatment time (Table 1). This suggests that the intensity of ultrasonic effect on physical structure, which facilitates moisture movement, increased with time. The longer ultrasonication time, the more mechanical stress is placed on the plant tissue structure. The forces involved in this mechanical stress can create micropores within the sample (de la Fuente-Blanco et al., 2006). Hence, the samples pretreated with longer ultrasonication time were expected to have more microporous structure and provide easier moisture removal during the hot air drying. Moreover, energy exerted from ultrasonic wave to the sample may detach strongly bound water, resulting in a better moisture reduction during drying. However, shorter ultrasonication time may not cause significant difference in moisture removal. Reduction in MC resulted in lower $\mathrm{a}_{\mathrm{w}}$. The MC and $\mathrm{a}_{\mathrm{w}}$ of the KMS pretreated sample were not significantly different as compared to those of the sample with ultrasonic pretreatment for $10 \mathrm{~min}(P>0.05)$. However, those of the samples with 20 and 30 min of ultrasonic pretreatment were significantly lower than those of the control samples $(P \leq 0.05)$.

Table 1. Chemical properties of dried longan

\begin{tabular}{cccccc}
\hline Treatment & $\mathrm{a}_{\mathrm{w}}$ & $\begin{array}{c}\mathrm{MC} \\
(\% \text { wet basis })\end{array}$ & $\begin{array}{c}\text { TSS } \\
\left({ }^{\mathrm{o}} \text { Brix }\right)\end{array}$ & $\begin{array}{c}\text { TA } \\
(\% \text { citric acid })\end{array}$ & $\mathrm{pH}$ \\
\hline Control & $0.502^{\mathrm{a}} \pm 0.013$ & $14.84^{\mathrm{a}} \pm 0.10$ & $14.27^{\mathrm{a}} \pm 0.23$ & $0.48^{\mathrm{b}} \pm 0.04$ & $6.75^{\mathrm{c}} \pm 0.05$ \\
KMS & $0.463^{\mathrm{b}} \pm 0.009$ & $14.34^{\mathrm{b}} \pm 0.10$ & $12.60^{\mathrm{b}} \pm 0.17$ & $0.56^{\mathrm{a}} \pm 0.04$ & $6.60^{\mathrm{d}} \pm 0.10$ \\
UP10 & $0.461^{\mathrm{b}} \pm 0.009$ & $14.28^{\mathrm{b}} \pm 0.03$ & $12.37^{\mathrm{bc}} \pm 0.23$ & $0.40^{\mathrm{c}} \pm 0.00$ & $6.79^{\mathrm{c}} \pm 0.01$ \\
UP20 & $0.429^{\mathrm{c}} \pm 0.004$ & $14.07^{\mathrm{c}} \pm 0.05$ & $12.10^{\mathrm{c}} \pm 0.10$ & $0.34^{\mathrm{d}} \pm 0.02$ & $6.98^{\mathrm{b}} \pm 0.01$ \\
& & & & & \\
UP30 & $0.426^{\mathrm{c}} \pm 0.018$ & $13.91^{\mathrm{d}} \pm 0.04$ & $12.10^{\mathrm{c}} \pm 0.17$ & $0.35^{\mathrm{cd}} \pm 0.03$ & $7.09^{\mathrm{a}} \pm 0.01$
\end{tabular}

Means within a row followed by different letters were significantly different $(P \leq 0.05)$.

The effect of high power ultrasonic pretreatment on color of dried longan is shown in Table 2. These result demonstrates that red color $\left(\mathrm{a}^{*}\right)$ decreased while yellow color $\left(\mathrm{b}^{*}\right)$ increased gradually when the sample was pretreated with increasing ultrasonication time. The decreasing in yellow color may be due to slight inactivation of POD and PPO activity during the high power ultrasonic pretreatment.

Table 2. Physical properties of dried longan

\begin{tabular}{ccccc}
\hline Treatment & $\mathrm{L}^{*}$ & $\mathrm{a}^{*}$ & $\mathrm{~b}^{*}$ & Firmness (N) \\
\hline Control & $43.00^{\mathrm{c}} \pm 3.39$ & $8.09^{\mathrm{a}} \pm 1.82$ & $15.71^{\mathrm{b}} \pm 0.89$ & $68.20^{\mathrm{c}} \pm 9.91$ \\
KMS & $49.35^{\mathrm{a}} \pm 2.23$ & $3.88^{\mathrm{c}} \pm 1.46$ & $17.04^{\mathrm{ab}} \pm 1.16$ & $85.64^{\mathrm{b}} \pm 10.04$ \\
UP10 & $45.32^{\mathrm{bc}} \pm 1.76$ & $6.05^{\mathrm{b}} \pm 1.38$ & $17.07^{\mathrm{ab}} \pm 1.45$ & $90.61^{\mathrm{ab}} \pm 8.41$ \\
UP20 & $47.03^{\mathrm{ab}} \pm 0.39$ & $5.23^{\mathrm{bc}} \pm 1.24$ & $17.90^{\mathrm{a}} \pm 0.85$ & $91.65^{\mathrm{ab}} \pm 12.99$ \\
& & & & \\
UP30 & $48.24^{\mathrm{ab}} \pm 2.06$ & $4.41^{\mathrm{bc}} \pm 1.05$ & $18.39^{\mathrm{a}} \pm 1.90$ & $98.34^{\mathrm{a}} \pm 12.88$ \\
\hline
\end{tabular}

Means within a column with different superscripts were significantly different $(P \leq 0.05)$. 
Analysis of the texture of dried longan (Table 2) revealed that firmness increased when ultrasonicpretreatment time increased. The firmness of the ultrasonic pretreated-dried longan ranged between 90.61-98.34 N, whereas that of the control sample was $68.20 \mathrm{~N}$. This result means that pretreatment with high power ultrasound of longan before air dehydration brought into the higher stress; at maximum forces applied, than air dehydrated longans. The firmness increased due to loss of moisture during drying, as can be seen that the sample with the lowest $\mathrm{MC}$ had the highest firmness value.

Figure 1 and 2 display the PPO and POD activities of high power ultrasonic pretreated-dried longan, as compared to KMS pretreated and control samples. It was found that increasing sonication time increased enzymatic inactivation. The high power ultrasonic pretreatment for $30 \mathrm{~min}$ could inhibit the PPO and POD activities by $70.68 \%$ and $94.06 \%$, respectively (Table 3). Inactivation of enzymes by ultrasonication for $30 \mathrm{~min}$ was higher than those of the control sample, KMS pretreated and10 and 20 min ultrasonic pretreated samples. This result was supported by the work of Ercan \& Soysal (2011), which reported that inactivation rate increased with increased ultrasonic power and time. In their work, complete inactivation of POD activity was achieved at $50 \%$ ultrasonic power for $150 \mathrm{~s}$ and at $75 \%$ power for $90 \mathrm{~s}$. Likewise, the result of this study shows that time had a significant effect $(P \leq 0.05)$ on the inactivation of longan's PPO and POD.

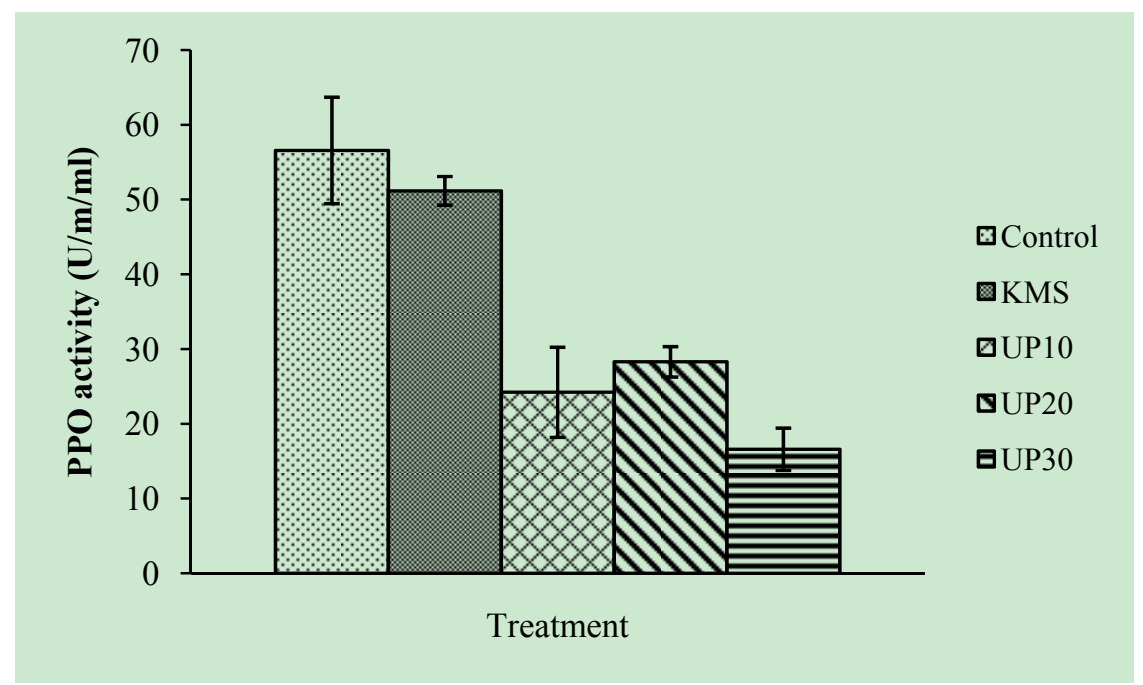

Figure 1. PPO activity of dried longan with different pretreatment methods

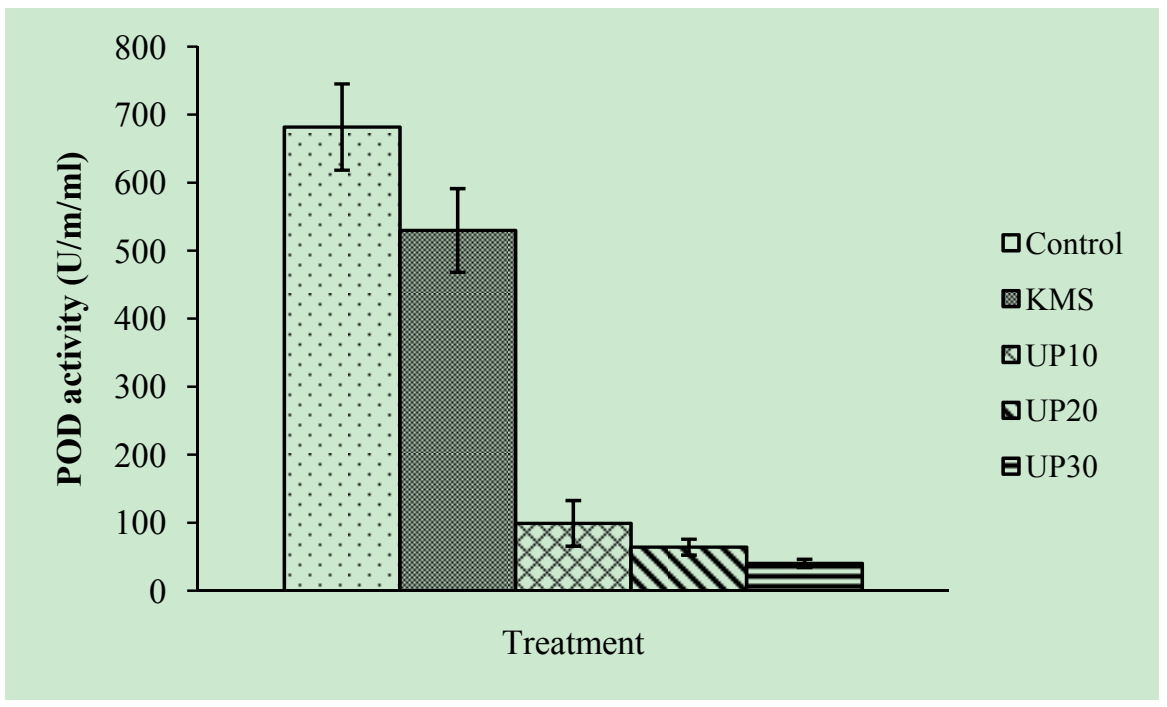

Figure 2. POD activity of dried longan with different pretreatment methods 
The application of ultrasonic pretreatment for 10, 20, and 30 min markedly reduced PPO and POD activities in dried longan. The application of high power ultrasonic pretreatment for 10, 20, and $30 \mathrm{~min}$, could reduce PPO activity by $49.99 \%, 57.18 \%$, and $70.68 \%$, and POD activity by $47.63 \%, 86.16 \%$, and $94.06 \%$, respectively (Table 3). Longer exposure time to high power ultrasonic wave increases it lethality on protein denaturation (Torley \& Bhandari, 2007). Hence, greater extent of enzymatic inactivation was achieved. Physical stress due to bubble collapse can contribute toward enzymatic inactivation. Enzymatic inactivation can also be affected by high shear generated by the interaction of the cavitating bubbles with the acoustic field (Ercan \& Soysal, 2011). The pretreatment of fresh longan with high power ultrasound before drying significantly reduced the enzymatic activities in the dried sample. Pretreatment of longan at $30 \mathrm{~min}$ could inhibit the highest percentages of PPO and POD inactivations. Hence, the rate of biochemical changes in those pretreated samples can be reduced and the shelf life of dried longan can be extended.

Table 3. The percentage inhibition of PPO and POD of dried longan

\begin{tabular}{ccccc}
\hline \multirow{2}{*}{ Treatment } & \multicolumn{2}{c}{ PPO } & \multicolumn{2}{c}{ POD } \\
\cline { 2 - 5 } & $\begin{array}{c}\text { Activity } \\
(\mathrm{U} / \mathrm{m} / \mathrm{ml})\end{array}$ & $\begin{array}{c}\text { Inhibition } \\
(\%)\end{array}$ & $\begin{array}{c}\text { Activity } \\
(\mathrm{U} / \mathrm{m} / \mathrm{ml})\end{array}$ & $\begin{array}{c}\text { Inhibition } \\
(\%)\end{array}$ \\
\hline Control & $56.57^{\mathrm{a}} \pm 7.12$ & - & $682.14^{\mathrm{a}} \pm 63.39$ & - \\
KMS & $51.17^{\mathrm{a}} \pm 1.92$ & $9.53^{\mathrm{c}} \pm 3.40$ & $530.03^{\mathrm{b}} \pm 61.47$ & $25.30^{\mathrm{d}} \pm 9.01$ \\
UP10 & $24.22^{\mathrm{b}} \pm 6.03$ & $49.99^{\mathrm{b}} \pm 3.58$ & $99.41^{\mathrm{c}} \pm 33.55$ & $47.63^{\mathrm{c}} \pm 17.15$ \\
UP20 & $28.29^{\mathrm{b}} \pm 2.03$ & $57.18^{\mathrm{b}} \pm 10.66$ & $64.42^{\mathrm{d}} \pm 11.69$ & $86.16^{\mathrm{b}} \pm 1.71$ \\
UP30 & $16.59^{\mathrm{c}} \pm 2.84$ & $70.68^{\mathrm{a}} \pm 5.03$ & $40.52^{\mathrm{d}} \pm 5.91$ & $94.06^{\mathrm{a}} \pm 0.87$ \\
\hline
\end{tabular}

Means within a column with different superscripts were significantly different $(P \leq 0.05)$.

Table 4.Sensory qualities of dried longan

\begin{tabular}{cccccc}
\hline \multirow{2}{*}{ Treatment } & \multicolumn{5}{c}{ Preference score } \\
\cline { 2 - 6 } & Color & Odor & Sweetness & Stickiness & Overall \\
\hline Control & $6.64^{\mathrm{bc}^{\mathrm{c}}} \pm 1.21$ & $6.80^{\mathrm{a}} \pm 1.14$ & $6.96^{\mathrm{ab}} \pm 1.40$ & $6.32^{\mathrm{b}} \pm 1.61$ & $6.78^{\mathrm{bc}} \pm 1.33$ \\
KMS & $6.26^{\mathrm{c}} \pm 1.86$ & $5.78^{\mathrm{b}} \pm 1.47$ & $6.78^{\mathrm{b}} \pm 1.09$ & $6.28^{\mathrm{b}} \pm 1.71$ & $6.57^{\mathrm{c}} \pm 1.48$ \\
UP10 & $6.70^{\mathrm{bc}} \pm 1.30$ & $6.72^{\mathrm{a}} \pm 1.01$ & $6.84^{\mathrm{b}} \pm 1.33$ & $6.96^{\mathrm{a}} \pm 1.32$ & $6.75^{\mathrm{bc}} \pm 1.24$ \\
& & & & & \\
UP20 & $6.92^{\mathrm{b}} \pm 1.23$ & $6.86^{\mathrm{a}} \pm 1.26$ & $7.10^{\mathrm{ab}} \pm 1.16$ & $7.44^{\mathrm{a}} \pm 0.93$ & $7.11^{\mathrm{ab}} \pm 1.19$ \\
UP30 & $7.54^{\mathrm{a}} \pm 0.76$ & $7.16^{\mathrm{a}} \pm 1.36$ & $7.38^{\mathrm{a}} \pm 0.97$ & $7.08^{\mathrm{a}} \pm 1.23$ & $7.50^{\mathrm{a}} \pm 0.89$ \\
\hline
\end{tabular}

Means within a column with different superscripts were significantly different $(P \leq 0.05)$.

Table 4 shows preference scores for the dried longan. The product specific color, odor, sweetness, stickiness, and overall acceptability scores for pretreated samples were significantly higher than those for control samples $(P \leq 0.05)$. Panelists were most satisfied with sensory characteristics of the dried longan with 30 min high power ultrasonic pretreatment. The stickiness scores for $20 \mathrm{~min}$ ultrasonic pretreated dried samples were slightly higher than that of at $30 \mathrm{~min}$ pretreated sample because the texture of the latter sample was slightly harder. The scores 
for color were increased when ultrasonic pretreatment time increased due to the color of dried longan became more golden-yellow which is the characteristic color of good quality dried longan. The score for sweetness of the samples with ultrasonication time for $30 \mathrm{~min}$ as the highest. This product can be an alternative low sugar dried fruit for consumers. Therefore, this technique may be applied for commercial production of high quality and low-sugar dried fruits.

\section{Conclusion}

The use of high power ultrasonic pretreatment had significant effects on physicochemical qualities and enzymatic activities of dried longan. Panelists were most satisfied with sensory properties of the dried longan with $30 \mathrm{~min}$ of high power ultrasonic pretreatment. High power ultrasonic pretreatment significantly altered the physical and biochemical properties of longan flesh. Ultrasound helped moisture removal from longan flesh during hot air drying, resulting in lower final $\mathrm{MC}$ and $\mathrm{a}_{\mathrm{w}}$ of the dried samples. Color properties of the ultrasonic pretreated samples were better than those of the control sample after drying, which was due to greater reduction of browning enzymes (PPO and POD). Texture of the dried longan was more firmed than non-ultrasonic pretreated samples. Increasing ultrasonic pretreated time generally gave beneficial effects on moisture reduction, enzymatic inactivation, color and texture improvement.

\section{Acknowledgements}

This research was financially supported by Office of the Higher Education Commission, Thailand. The authors greatly acknowledge this support.

\section{References}

Achariyaviriya, A., Soponronnarit, S., \& Tiansuwan, J. Study of longan flesh drying. (2001). Drying Technology, 19(9), 2315-2329. http://dx.doi.org/10.1081/DRT-100107501

AOAC (2000). Official methods of analysis (15th ed.). VA: Association of Official Analytical Chemists, Arlington.

Attabhanyo, R., \& Tiampakdee, A. (1998). Storage methods of fresh for commercial dried flesh loganproduction. Thesis. Department of Food Science and Technology, Faculty of Agro-Industry, Chiangmai University, Chiangmai, Thailand.

Cárcel, J. A., Benedito, J., Rosselló , C., \& Mulet, A. (2007). Influence of ultrasound intensity on masstransfer in apple immersed in a sucrose solution. Journal of Food Engineering, 78, 472-479. http://dx.doi.org/10.1016/j.jfoodeng.2005.10.018

Da-Mota, V. M., \& Palau, E. (1999). Acoustic drying of onion. Drying Technology, 17, 855-867. http://dx.doi.org/10.1080/07373939908917574

de la Fuente-Blanco, S., Sarabia, E. R. F., Acosta-Aparicio, V. M., Blanco-Blanco, A., \& Gallego-Juárez, J. A. (2006). Food drying process by power ultrasound. Ultrasonics Sonochemistry, 44, 523-527.

Ercan, S. S., \& Soysal, C. (2011). Effect of ultrasound and temperature on tomato peroxidase. Ultrasonics Sonochemistry, 18, 689-695. http://dx.doi.org/10.1016/j.ultsonch.2010.09.014

Fernandes, F. A. N., \& Rodrigues, S. (2007). Ultrasound as pre-treatment for drying of fruits: dehydration of banana. Journal of Food Engineering, 82, 261-267. http://dx.doi.org/10.1016/j.jfoodeng.200702.032

Fernandes, F. A. N., Gallão, M. I., \& Rodrigues, S. (2008a). Effect of osmotic dehydration and ultrasound pre-treatment on cell structure: melon dehydration. Food Science and Technology, 41, 604-610.

Fernandes, F. A. N., Francisca I. P. O., \& Rodrigues, S. (2008b). Use of ultrasound for dehydration of papayas. Food Bioprocess Technology, 1, 339-345. http://dx.doi.org/ 10.1007/s11947-007-0019-9

Fernandes, F. A. N., Gallão, M. I., \& Rodrigues S. (2009). Effect of osmosis and ultrasound on pineapple cell tissue structure during dehydration.Journal of Food Engineering, 90, 186-190. http://dx.doi.org/10.1016/j.jfoodeng.2008.06.021

Fernandes, F. A. N., Rodrigues, S., Law. C. L., \& Mujumdar, A. S. (2010). Drying of Exotic Tropical Fruits: A Comprehensive Review. Food Bioprocess Technology. http://dx.doi.org/10.1007/s11947-010-0323-7

Gallego-Juárez, J. A., Rodríguez-Corral, G., Gálvez-Moraleda, J. C., \& Yang, T. S. (1999). A new high intensity ultrasonic technology for food dehydration. Drying Technology, 17, 597-608. http://dx.doi.org/10.1080/07373939908917555

Janjai, S., Bala, B. K., Lamlert, N., Mahayothee, B., Haewsungcharern, M., Muhlbauer, W., \& Muller, J. (2007). 
Moisture diffusivity determination of different parts of longan fruit. International Journal of Food Properties, 10, 471-478. http://dx.doi.org/10.1080/10942910600889968

Jiang, Y. M., \& Li, Y. B. (2001). Effects of chitosan coating on postharvest life and quality of longan fruit. Food Chemistry, 73, 139-143. http://dx.doi.org/10.1016/S0308-8146(00)00246-6

Kaewnarin, K. (2008). Effect of enzyme inactivation by microwave pretreatment on the quality of dried-longan pulp. M.S. Thesis, Department of Biotechnology Faculty of Graduated school, Chiang Mai University, Chiang Mai, Thailand.

Lin, Z. F., Li, S. S., Zhang, D. L., Liu, S.X., Li, Y. B., Lin, G. Z., \& Chen, M. D. (1988). The changes of pigments, phenolic content and activities of polyphenol oxidase and phenylalanine ammonialyase in pericarp of postharvest litchi fruit. Acta Botanica Sinica, 30, 40-45.

Pongsakul, N., Leelasart, B., \& Rakariyatham, N. (2006). Effect of L-cysteine, potassium metabisulfite, ascorbic acid and citric acid on inhibition of enzymatic browning in longan. Chiang Mai Journal of Science, 33(1), 137-141.

Rodrigues, S., \& Fernandes, F. A. N. (2007). Dehydration of melons in a ternary system followed by air-drying. Journal of Food Engineering, 80, 678-687. http://dx.doi.org/10.1016/j.jfoodeng2006.07.004

Shewfelt, R. L. (1987). Quality of minimally processed fruits and vegetables. Journal of Food Quality, 10, 143-156. http://dx.doi.org/10.1111/j.1745-4557.1987.tb00855.x

Simal, S., Benedito, J., Sánchez, E. S., \& Rosselló , C. (1998). Influence of ultrasound to increase mass transport rates during osmotic dehydration. Journal of Food Engineering, 36, 323-336. http://dx.doi.org/10.1016/S0260-8774(98)00053-3

Torley, P. J., \& Bhandari, B. R. (2007). Handbook of Food Preservation. (2nd ed.). Taylor and Francis, (Chapter 29), Boca Raton: CRC Press.

Walkling-Ribeiro, M., Noci, F., Cronin, D. A., Lyng, J. G., \& Morgan, D. J. (2009). Shelf life and sensory evaluation of orange juice after exposure to thermosonication and pulsed electric fields. Food and Bioproducts Processing, 87, 102-107. http://dx.doi.org/10.1016/j.fbp.2008.08.001 